\title{
PENJATUHAN SANKSI TERHADAP ANGGOTA POLRI YANG TERBUKTI MENGGUNAKAN NARKOTIKA GOLONGAN 1
}

\author{
Oleh : \\ Iskandar Zulkarnain* \\ Abdul Bari Azed*
}

\begin{abstract}
ABSTRAK
Anggota-anggota Polisi yang tersebar di dalam wilayah hukum Kepolisian Republik Indonesia dalam melaksanakan tugas dan tanggung jawab sebagaimana termaktub dalam Undang Undang Nomor 2 tahun 2002 tentang Kepolisian Negara Republik Polri terjadi pelanggaran disiplin dan terlibat tindak pidana seperti yang berkaitan dengan penelitian ini yaitu anggota Polri yang terbukti menggunakan narkotika golongan I. Narkotika golongan I berdasarkan Undang Undang No. 35 tahun 2009 tentang Narkotika Pasal 8 merupakan golongan narkotika yang dilarang digunakan untuk pelayanan kesehatan, tetapi dalam jumlah terbatas, narkotika golongan 1 dapat digunakan untuk kepentingan ilmu pengetahuan dan teknologi dan untuk reagensia dianostik serta reagensia laboratorium setelah mendapatkan persetujuan menteri setelah atas persetuan kepala badan pengawas obat dan makanan. Terkait dengan pelanggaran disiplin dan perbuatan pidana yang dilakukan oleh anggota Polri dalam penggunaan narkotika golongan I , diperoleh tujuan penulisan menjelaskan dan menganalisis proses penegakan hukum terhadap anggota POLRI yang terbukti menggunakan narkotika Golongan I dan penerapan sanksi terhadap anggota POLRI yang terbukti menggunakan narkotika Golongan I
\end{abstract}

Kata Kunci: Sanksi, Anggota Polri, Penguna Narkotika Golongan I

\section{A. Latar Belakang Masalah}

Perbuatan pidana penggunaan golongan I yang dilakukan oleh oknum polisi ini berakibat masyarakat menjadi prihatin dimana anggota Polri yang diharapkan mampu menjadi benteng kokoh penegakan hukum, justeru melakukan pelanggaran disiplin bahkan melakukan tindak pidana, Dikatehui bahwa fungsi dan peran Kepolisian Negara Republik Indonesia dari masa ke masa selalu menjadi bahan perbincangan berbagai kalangan, mulai dari praktisi hukum maupun akademis bahkan masyarakat kebanyakan dan pada umumnya mereka berusaha memposisikan secara positif kedudukan, fungsi dan peranan Kepolisian tersebut. Upaya pengupasan masalah Kepolisian itu dikarenakan adanya faktor kecintaan dari berbagai pihak kepada Lembaga Kepolisian dan ditaruhnya harapan yang bergitu besar, agar fungsinya sebagai aparakat penegak

\footnotetext{
* Anggota Polisi di POLDA Jambi, Alumni Program Magister Ilmu Hukum Unbari.

* Pengajar Program Magister Ilmu Hukum Unbari.
} 
hukum bisa berjalan sebagaimana mestinya. Juga tidak bisa berhenti sampai disitu, atensi itu termasuk juga merubah struktur Kepolisian secara kelembagaan, dimana organisasi Kepolisian mulai dari bawah Institusi Sipil, ABRI/Militer, sampai dengan berdiri sendiri merupakan sejarah yang unik.

Dilihat Posisi Kepolisian RI sejak Proklamasi Kemerdekaan 17 Agustus 1945 kerap kali mengalami perubahan. Oleh karena itu wawasan paradigma kepolisian yang mandiri, professional dan merakyat kedepan perlu terus mendapat pemikiran yang kontruktif dan inovatif untuk menempatkan kedudukan atau posisi kepolisian yang tepat dan efektif dalam sistem ketatanegaraan Indonesia. Hal ini telah dimuat dalam Garis-Garis Besar Haluan Negara Tahun 1988-1993 pada pembangunan peranan Polri dalam bidang-bidang Pertahanan Keamanan point I a disebutkan:

Pembinaan Kemananan Umum dan Ketentraman masyarakat ditujukan kepada usaha untuk mengembangkan sistem keamanan dan ketertiban masyarakat yang bersifat swakarsa. Polri sebagai alat negara penegak hukum yang mahir, terampil, bersih dan berwibawa. Dalam hal ini lebih diutamakan usaha-usaha pencegahan dan penegakalan, sedangkan pembinaan kesadaran masyarakat terhadap keamanan dan ketertiban masyarakat terhadap keamanan dan ketertiban masyarakat terus ditingkatkan.

Seiring dengan perubahan - perubahan sesuai kebijakan politik tersebut di atas, maka citra Kepolisian terus melekat, karena baik positif maupun negatif. Sebagai pelaksana fungsi pemerintahan di bidang penegakan hukum, Kepolisian Republik Indonesia melaksanakan tugas memerangi tingkah laku yang bervariatip atas ketertiban yang terjadi di masyarakat.

Dinamika masyarakat yang berubah dengan cepat, diiringi dengan perubahan sosial budaya dan teknologi, sementara di sisi lain perkembangan tingkat kesejahteraan juga semakin kompleks, menuntut begitu tinggi peran Kepolisian untuk mengatasi berbagai pelanggaran hukum yang terjadi termasuk juga pelanggaran hukum yang dilakukan oleh oknum anggota Polri sendiri.

Terkait dengan pelanggaran disiplin dan perbuatan pidana yang dilakukan oleh anggota Polri dalam penggunaan narkotika golongan I , pertanyaan yang relevan untuk diajukan adalah bagaimana proses sanksi terhadap anggota POLRI yang terbukti menggunakan narkotika Golongan I dan sanksi apakah terhadap anggota POLRI yang 
terbukti menggunakan narkotika Golongan I, apakah ada perbedaan sanksi terhadap anggota POLRI yang terbukti menggunakan narkotika golongan I dengan anggota POLRI yang terbukti juga sebagai pengedar, dan juga apakah juga ditemukan hambatan dalam penerapan sanksi bagi anggota anggota POLRI yang terbukti menggunakan narkotika golongan I dalam rangka mencegah tidak terjadi kembali pelanggaran oleh anggota Polri sehingga pelaksanaan tugas Kepolisian dalam memelihara keamanan dan ketertiban masyarakat, menegakkan hukum, serta melindungi, mengayomi, dan melayani masyarakat, dapat dilaksanakan dengan optimal.

\section{B. Perumusan Masalah}

Berdasarkan latar belakang yang telah diuraikan di atas, maka rumusan masalah adalah:

1. Bagaimanakah proses penegakan hukum terhadap anggota POLRI yang terbukti menggunakan narkotika Golongan I ?

2. Bagaimanakah penerapan sanksi terhadap anggota POLRI yang terbukti menggunakan narkotika Golongan I?

\section{Metode Penelitian}

1. Spesifikasi Penelitian

Spesifikasi dalam penelitian ini adalah penelitian deskriptif analitis, yaitu penelitian yang mendeskripsikan secara terperinci fenomena sosial yang menjadi pokok permasalahan. Suatu penelitian diskriptif dimaksudkan untuk memberikan data yang seteliti mungkin tentang korban, keadaan atau gejala-gejala lainnya. ${ }^{1}$

2. Metode Pendekatan

Penelitian tentang Analisis Yuridis Penjatuhan Sanksi Terhadap Anggota Polri Yang Terbukti Menggunakan Narkotika Golongan I ini menggunakan pendekatan yang bersifat yuridis normatif, yaitu dengan mengkaji/menganalisis data sekunder yang berupa bahan-bahan hukum terutama bahan hukum primer dan bahan hukum sekunder dengan memahami hukum sebagai seperangkat peraturan atau normanorma positif didalam sistem perundang-undangan yang mengatur mengenai kehidupan manusia.

\footnotetext{
1 Soerjono Soekanto, Pengantar Penelitian hukum, Jakarta, UI PRESS, 1986, hal. 10.
} 
Penelitian hukum normatif merupakan penelitian yang dilakukan dengan cara meneliti bahan pustaka. Penelitian hukum normatif atau kepustakaan ini mencakup : (1) penelitian terhadap asas-asas hukum; (2) penelitian terhadap sistematika hukum; (3) penelitian terhadap taraf sinkronisasi vertikal dan horizontal; (4) perbandingan hukum; dan (5) sejarah hukum. ${ }^{2}$

Analisis bahan hukum dilakukan dengan meneliti pengertian-pengertian hukum dan norma-norma hukum. Dengan cara melihat isi dari berbagai macam peraturan perundang-undangan yang berhubungan dengan hak-hak korban kejahatan. Penganalisisan terhadap isi bahan hukum dengan melakukan intreprestasi, menilai dan melakukan evaluasi terhadap semua kebijakan hukum pidana yang berhubungan dengan hak-hak korban kejahatan.

\section{Penjatuhan Sanksi Terhadap Anggota Polri Yang Terbuktimenggunakan Narkotikagolongan I}

1. Proses Penegakan Hukum Terhadap Anggota POLRI Yang Terbukti Menggunakan Narkotika Golongan I

Anggota-anggota Polisi yang tersebar di dalam wilayah hukum Kepolisian Republik Indonesia dalam melaksanakan tugas dan tanggung jawab sebagaimana termaktub dalam Undang Undang Nomor 2 tahun 2002 tentang Kepolisian Negara Republik Polri terjadi pelanggaran disiplin dan terlibat tindak pidana seperti yang berkaitan dengan penelitian ini yaitu anggota Polri yang terbukti menggunakan narkotika golongan I. Narkotika golongan I berdasarkan Undang Undang No. 35 tahun 2009 tentang Narkotika Pasal 8 merupakan golongan narkotika yang dilarang digunakan untuk pelayanan kesehatan, tetapi dalam jumlah terbatas, narkotika golongan 1 dapat digunakan untuk kepentingan ilmu pengetahuan dan teknologi dan untuk reagensia dianostik serta reagensia laboratorium setelah mendapatkan persetujuan menteri setelah atas persetuan kepala badan pengawas obat dan makanan.

Selanjutnya Anggota Polri yang terbukti menggunakan narkotika golongan I adalah termasuk tindak pidana. Yang dimaksud dengan tindak pidana Polri dengan tindak pidana, yang dilakukan oleh anggota Polri, adalah perbuatan pidana yang dimaksud di dalam KUHP dan/atau peraturan perundangan pidana di luar KUHP. Disamping itu, menurut

\footnotetext{
${ }^{2}$ Soerjono Soekanto dan Sri Mamuji, Penelitian Hukum Normatif "Suatu Tinjauan Singkat", Jakarta, PT Raja Grafindo Persada, 2004, hal. 14
} 
ketentuan Pasal 12 Peraturan Pemerintah Nomor 1 Tahun 2003 tentang Pemberhentian Anggota Kepolisian Negara Republik Indonesia, terdapat 2 (dua) perbuatan yang digolongkan sebagai tindak pidana, adalah apabila diketahui kemudian memberikan keterangan palsu dan/atau tidak benar pada saat mendaftarkan diri sebagai calon anggota Kepolisian Negara Republik Indonesia, dan melakukan usaha atau kegiatan yang nyatanyata bertujuan mengubah Pancasila, terlibat dalam gerakan, atau melakukan kegiatan yang menentang negara dan/atau Pemerintah Republik Indonesia secara tidak sah.

Sehingga tindak pidana yang dilakukan oleh seorang oknum anggota Polri tidak lagi diselesaikan melalui peradilan militer akan tetapi sudah masuk ke-dalam wilayah peradilan umum di bidang hukum disiplin dan penyelesaian perkara bagi anggota Polri tidak lagi diselesaikan melalui sistem peradilan Militer yang mengarah pada hukum Militer. Namun proses penyelesaian secara hukum dengan mengacu kepada sistem peradilan umum bagi anggota Polri yang melakukan tindak pidana, sedangkan pelanggaran disiplin diselesaikan melalui proses penyelesaian Disiplin dengan mengacu pada Peraturan pemerintah RI Nomor 2 Tahun tahun 2003 tentang Peraturan Disiplin Anggota polri dan peraturan Pemerintah RI Nomor 3 Tahun 2003 tentang Pelaksanaan Teknis institusional peradilan Umum bagi anggota polri.

Namun terdapat perbedaan terhadap oknum pidana dari sipil dibandingkan anggota Polri yang melakukan tindak pidana mengenai penyidiknya dimana penyidiknya adalah penyidik Propos atau Propam.

Proses penegakan hukum bagi anggota Polri yang telah diperoleh bukti awal yang cukup sebagai pelaku tindak pidana, maka anggota Polisi itu, diserahkan kepada Ditreskrim Polisi Daerah tempat satuan tertangkap untuk menjalani penahanan dan proses peradilan mulai dari tingkat penyidik sampai kepada pengadilan untuk mendapatkan kepastian hokum tetap menurut system peradilan pidana Indonesia.

Pasal 20 KUHAP menentukan proses penahan anggota polri dilakukan untuk kepentingan penyidikan, selanjutnya kepentingan penuntutan, penuntut umum berwenang melakukan penahanan atau penahanan lanjutan, begitupun untuk kepentingan pemeriksaan hakim di sidang pengadilan dengan penetapannya berwenang melakukan penahanan.

Proses penegakan hokum terhadap anggota polri yang terbukti menggunakan narkotika maupun bertindak sebagai pengedar tidak ada perbedaan. Keduanya diproses menurut sistem peradilan pidana di Indonesia. 
Pengaturan hukum bagi pengguna narkotika golongan I, termaktub di dalam pasal 111 , 112, 113, 114 dan Pasal 127 ayat (1) huruf a Undang- undang No. 35 Tahun 2009 tentang Narkotika. Setiap penyalahguna Narkotika golongan I bagi diri sendiri diancam dengan hukuman paling lama 4 tahun, maka anggota polri yang terbukti menggunakan Narkotika golongan I diancam dengan pidana penjara paling lama 4 tahun. Berdasarkan pasal 2 sampai dengan pasal 5 , pasal 7, dan pasal 8 KUHP, yang dimaksud barang siapa adalah setiap orang yang tunduk dan dapat dipertanggungjawabkan artinya dapat dipertanggungjawabkan atas perbuatannya secara hukum. Subjek hukum tersebut meliputi semua orang WNI, termasuk yang bersetatus penegak hukum yang pada waktu melakukan tindak pidana masih aktif dalam kedinasan.

Berdasarkan Pasal 12 ayat (1) huruf a PP No. 1 Tahun 2003 tentang Pemberhentian Anggota Kepolisian Negara Republik Indonesia anggota POLRI tersebut terancam diberhentikan tidak hormat, dinyatakan sebagai berikut:

Pasal 12

(1) Anggota Kepolisian Negara Republik Indonesia diberhentikan tidak dengan hormat dari dinas Kepolisian Negara Republik Indonesia apabila:

a. dipidana penjara berdasarkan putusan pengadilan yang telah mempunyai kekuatan hukum tetap dan menurut pertimbangan pejabat yang berwenang tidak dapat dipertahankan untuk tetap berada dalam dinas Kepolisian Negara Republik Indonesia;

b. diketahui kemudian memberikan keterangan palsu dan/atau tidak benar pada saat mendaftarkan diri sebagai calon anggota Kepolisian Negara Republik Indonesia;

c. melakukan usaha atau kegiatan yang nyata-nyata bertujuan mengubah Pancasila, terlibat dalam gerakan, atau melakukan kegiatan yang menentang negara dan/atau Pemerintah Republik Indonesia secara tidak sah.

Dengan demikian, walaupun si oknum polisi sudah dipidana berdasarkan putusan pengadilan yang telah berkekuatan hukum tetap, oknum polisi tersebut baru dapat diberhentikan dengan tidak hormat apabila menurut pertimbangan pejabat yang berwenang dia tidak dapat dipertahankan untuk tetap berada dalam dinas kepolisian .

Pemberhentian anggota kepolisian dilakukan setelah melalui sidang Komisi Kode Etik Profesi Kepolisian Negara Republik Indonesia sebagaimana termaktub Pasal 12 ayat [2] PP Nomor 1 Tahun 2003

Pasal 12 
(2) Pemberhentian sebagaimana dimaksud dalam ayat (1) dilakukan setelah melalui sidang Komisi Kode Etik Profesi Kepolisian Negara Republik Indonesia.

Proses penegakan sanksi disipilin diawali dengan setelah anggota polri menjalankan sanksi pidana dari proses peradilan umum yang telah berkekuatan hokum dengan melakukan laporan kepada kesatuan dimana terakhir anggota polisi ditugaskan. Selanjutnya oleh atasan yang terhukum (ANKUM) dikembalikan kepada Kesatuan Kepolisan Daerah (POLDA) Biro Sumber Daya Manusia sambil menunggu proses sidang kode etik oleh Bidang Propam POLDA.

Dalam proses sanksi bagi anggota polisi tersebut Bidang Propam melakukan pemeriksaaan oleh pemeriksa Pusbinprof atau pejabat yang berwenang atas pelanggaran Kode Etik Profesi Polri atau pelanggaran dengan sanksi PDH atau PTDH yang diduga dilakukan oleh anggota Polri dimulai dari adanya laporan / pengaduan sampai dengan penyerahan berkas perkara pelanggaran Kode Etik Profesi Polri kepada Sekretariat komisi kode etik Polri (SET KKE) atau pimpinan terperiksa guna dilaksanakan sidang komisi kode etik Polri.

Dalam melaksanakan tugas pemeriksaan terhadap anggota polisi yang melakukan pelanggaran disiplin dan tindak pidana, tahapan-tahapan kegiatan sebagai berikut :

a. Perencanaan

1) membuat rencana dan jadwal kegiatan pemeriksaan, yang memuat obyek pemeriksaan, petugas pelaksana pemeriksaan yang ditunjuk, materi pertanyaan pemeriksaan, administrasi pemeriksaan dan dukungan anggaran pemeriksaan;

2) sebelum kegiatan pemeriksaan dilaksanakan, terlebih dahulu kepada pimpinan terperiksa dan terperiksa diberitahu dipanggil secara resmi tentang adanya kegiatan pemeriksaan di lingkungan satuan kerja yang bersangkutan.

b. Pengorganisasian

1) pelaksanaan kegiatan pemeriksaan, didukung dengan surat perintah dari Kapolri atau surat perintah dari Kapolda untuk tingkat kewilayahan;

2) Setiap pemeriksaan satu perkara pelanggaran etika profesi Polri harus ditangani oleh Tim pemeriksa, dengan ketentuan setiap Tim pemeriksa sekurang-kurangnya dua orang pemeriksa.

c. Pelaksanaan

1) subyek pemeriksa 
a) pemeriksa Pusbinprof Divpropam Polri ditingkat Satker Mabes Polri dan Satker Kewilayahan;

b) pemeriksa Bidpropam / Subbid Binprof Bidpropam Polda ditingkat Satker Mapolda dan Satker kewilayahan / Polres dan Polsek.

2) obyek pemeriksa. Obyek pemeriksa adalah anggota Polri yang diduga telah melakukan pelanggaran kode etik profesi Polri dan atau pelanggaran dengan sanksi PDH/PTDH di seluruh satuan kerja Polri.

3) sasaran pemeriksaan. Sasaran pemeriksaan yaitu peristiwa atau pelanggaran kode etik profesi Polri yang dilakukan oleh anggota Polri dalam melaksanakan tugasnya;

4) metode pemeriksaan

a) analisis memecahkan / mengurai data / informasi ke dalam unsur-unsur yang lebih kecil atau bagian-bagian, sehingga dapat diketahui pola hubungan antar unsur atau unsur penting yang tersebunyi;

b) observasi / pengamatan peninjauan dan pengamatan atas suatu obyek secara teliti, ilmiah, dan kontinu selama kurun waktu tertentu untuk membuktikan suatu keadaan atau masalah yang sebenarnya berdasarkan fakta yang ada; wawancara (permintaan informasi) menggali informasi tertentu dari berbagai pihak yang berkompeten, dilakukan dengan mengajukan pertanyaan secara tertulis maupun secara lisan;

d) evaluasi, cara untuk memperoleh suatu kesimpulan dan pendapat / penilaian dengan mencari pola hubungan atau menghubungkan atau merakit berbagai informasi yang telah diperoleh, baik informasi / bukti intern maupun bukti ekstern;

e) pemeriksaan, melakukan pemeriksaan kepada saksi, ahli dan terperiksa untuk mendapat keterangan sebagai bahan penyusunan berkas perkara.

5) waktu pemeriksaan dan pemberkasan

a) waktu pemeriksaan dan pemberkasan pelanggaran kode etik profesi Polri dan atau pelanggaran dengan sanksi PDH / PTDH oleh anggota Polri dalam melaksanakan tugas, yaitu :

(1) kasus mudah paling lama 20 hari sejak diterimanya surat perintah pemeriksaan;

(2) kasus sedang paling 40 hari sejak diterimanyasurat perintah pemeriksaan;

(3) kasus sulit 60 hari sejak diterimanya surat perintah pemeriksaan; 
(4) kasus sangat sulit 90 hari sejak diterimanya surat perintah tugas.

b) kriteri tingkat kesulitan pemeriksan dan pemberkasan dilihat dari saksi, surat, petunjuk, ahli, terperiksa, tempat kejadian perkara, barang bukti, alat pendukung dan peran lembaga lain;

c) pejabat penentu tingkat kesulitan pemeriksaan dan pemberkasan adalah Kadivpropam Polri / Kapusbinprof dan Kabidpropam Polda / Kasubbid Binprofesi.

6) mekanisme pemeriksaan, mekanisme kegiatan pemeriksaan sebagai berikut :

a) kegiatan pemeriksaan dilaksanakan oleh pemeriksa Pusbinprof di Pusbinprof Divpropam Polri atau Mabes Polri atau pemeriksa Bidpropam Polda di Bidpropam Polda, dengan urutan kegiatan sebagai berikut:

(1) penerimaan laporan / pengaduan. laporan tentang dugaan telah terjadinya pelanggaran kode etik profesi Polri yang dilakukan oleh anggota Polri dalam melaksanakan tugasnya;

(2) penunjukan tim pemeriksa dengan surat perintah Kapolri / Kapolda; yang terdiri dari : Atasan Yang Menghukum, Kabid Propam, Inspektorat Pengawasan Daerah, Atasan langsung yang dihukum

(3) mempelajari laporan / pengaduan / surat / berkas / kasus tersebut

(4) membuat laporan kepada pimpinan (Kapusbinprof / Kadivpropam Polri / Kabidpropam Polda) tentang duduk permasalahan kasus yang dilaporkan;

(5) membuat rencana dan jadwal pemeriksaan;

(6) membuat surat membuat surat panggilan saksi, ahli dan terperiksa;

(7) menyampaikan surat panggilan saksi, ahli dan terperiksa;

(8) melaksanakan pemeriksaan saksi, ahli dan terperiksa;

(9) mengumpulkan bukti-bukti pelanggaran;

(10) membuat resume hasil pemeriksaan;

(11) melaksanakan gelar perkara;

(12) apabila memenuhi unsur pelanggaran kode etik profesi Polri dan atau pelanggaran dengan sanksi PDH atau PTDH, maka dilaksanakan penyusunan berkas;

(13) menyerahkan berkas perkara ke Sekretariat Komisi Kode Etik Polri (SET KKE) atau pimpinan terperiksa / Kasatwil untuk dilaksanakan sidang Komisi Kode Etik Polri; 
(14) apabila tidak memenuhi unsur pelanggaran kode etik profesi Polri dan atau pelanggaran dengan sanksi PDH atau PTDH, maka dilaksanakan penghentian pemeriksaan dengan membuat Surat pemberitahuan penghentian pemeriksaan Kode Etik Profesi Polri (SP3KEPP);

(15) membuat dan memberikan Surat Pemberitahuan Perkembangan Hasil Pemeriksaan Profesi (SP2HP2) kepada pelapor paling sedikit 1 kali selama proses pemeriksaan.

b) kegiatan pemeriksaan dilaksanakan di satker mabes Polri atau di satker kewilayahan, maka urutan kegiatan sebagai berikut:

(1) penerimaan laporan / pengaduan laporan tentang dugaan telah terjadinya pelanggaran kode etik profesi Polri yang dilakukan oleh anggota Polri dalam melaksanakan tugasnya;

(2) penunjukan tim pemeriksa dengan surat perintah Kapolri / Kapolda;

(3) mempelajari laporan / pengaduan / surat / berkas / kasus yang dilaporkan masyarakat;

(4) membuat laporan kepada pimpinan (Kapusbinprof / Kadivpropam Polri / Kabidpropam Polda) tentang duduk permasalahan kasus yang dilaporkan;

(5) membuat rencana dan jadwal pemeriksaan;

(6) memberitahukan rencana dan jadwal kegiatan pemeriksaan ke Kasatker atau Kasatwil yang menjadi obyek pemeriksaan;

(7) melaporkan kedatangan, maksud dan tujuan dilaksanakannya pemeriksaan ke Kasatker atau Kastwil obyek pemeriksaan;

(8) melakukan penelitian dokumen, berkas perkara, surat-surat yang berkaitan dengan peristiwa / kejadian atau pelaksanaan kegiatan kepolisian di tingkat pusat maupun kewilayahan;

(9) melakukan konfirmasi atau meminta penjelasan terhadap petugas pelaksana atau petugas lainnya sehubungan dengan peristiwa yang dilaporkan;

(10) melaksanakan pemeriksaan saksi, ahli dan terperiksa;

(11) mengumpulkan bukti-bukti pelanggaran;

(12) melaporkan kegiatan pemeriksaan telah selesai dilaksanakan ke Kasatker atau Kastwil obyek pemeriksaan;

(13) membuat resume hasil pemeriksaan;

(14) melaksanakan gelar perkara; 
(15) apabila memenuhi unsur pelanggaran kode etik profesi Polri dan atau pelanggaran dengan sanksi PDH atau PTDH, maka dilaksanakan penyusunan berkas;

(16) menyerahkan berkas perkara ke Sekretariat Komisi Kode Etik Polri (SET KKE) atau pimpinan terperiksa / Kasatwil untuk dilaksanakan sidang Komisi Kode Etik Polr;

(17) apabila tidak memenuhi unsur pelanggaran kode apabila tidak memenuhi unsur pelanggaran kode etik profesi Polri dan atau pelanggaran dengan sanksi PDH atau PTDH, maka dilaksanakan penghentian pemeriksaan dengan membuat Surat pemberitahuan penghentian pemeriksaan Kode Etik Profesi Polri (SP3KEPP);

(18) membuat dan memberikan Surat Pemberitahuan Perkembangan Hasil Pemeriksaan Profesi (SP2HP2) kepada pelapor paling sedikit 1 kali selama prose pemeriksaan

Dalam proses penegakan disipilin anggota polri yang melakukan pelanggaran disiplin dan tindak pidana bidang propam menghadapi berbagai kendala untuk itu diperlukan upaya-upaya dalam dalam menjaga kinerja dan peran anggota kepolisian. Untuk itu diperlukan rehabilitasi, sosialisasi upaya penyadaran yang bersifat sistemik, terencana dan berkelanjutan dalam melakukan pembinaan terhadap setiap anggota Polri. Dalam pembinaan penyadaran sistemik ini seperti Polda Jambi melalui bidang propamnya melakukan upaya-upaya dalam meminimalisir angka pelanggaran dan perbuatan pidana yang dilakukan oleh anggota Polri di wilayah hukum Polda Jambi.

Upaya - upaya yang dilakukan propam POLDA Jambi adalah :

1. Sosialisasi Peraturan Perundang-Undangan Terkait Tugas Polri

2. Penyadaran Kehormatan Profesi

3. Pelatihan Membangun Keteladanan (bagi para Pimpinan Satker dan Satwil)

4. Pemeriksaan/Penggeledahan/Razia Rutin

5. Pemeriksaan/Penggeledahan/Razia Insidentil

Upaya - upaya ini diharapkan kepada anggota Polri, agar dalam kehidupannya baik selaku pribadi maupun selaku penegak hukum, selalu terbiasa hidup tertib hukum atau taat asas, sedemikian sehingga tidak sampai melakukan pelanggaran terhadap peraturan disiplin, apalagi sampai melakukan pidana, yang dapat berakibat dijatuhi pidana penjara dan diberhentikan secara tidak hormat dari dinas kepolisian. 
Selanjutnya berkaitan dengan narkotika, setiap POLDA di Indonesia telah mendirikan pusat rehabilitasi narkotika di Sekolah Polisi Negara bekerjasama dengan Badan Narkotika Nasional (BNN) terhadap anggota polisi yang telah menjalani sidang kode etik polisi dengan sanksi harus menjalankan rehabilitasi narkotika hal ini dilaksanakan berdasarkan Pasal 54 Undang Undang Nomor 35 Tahun 2009 tentang narkotika yang termaktub sebagai berikut :

Pasal 54

Pecandu Narkotika dan korban penyalahgunaan Narkotika wajib menjalani rehabilitasi medis dan rehabilitasi social

Program rehabilitasi ini berupa bimbingan oleh konselor baik dari BNN berupa teknik rehabilitasi yang digunakan berupa pendekatan spiritual dan medis di samping pendekatan sosial sehingga bisa membangundan tidak lagi mengulangi perbuatan menggunakan narkotika.

\section{E. Kesimpulan}

Berdasarkan uraian yang telah dikemukakan pada bab diatas, maka kesimpulan dari hasil penelitian dan pembahasan adalah sebagai berikut :

1. Proses penegakan hukum terhadap anggota POLRI yang terbukti menggunakan narkotika Golongan I tidak lagi diselesaikan melalui peradilan militer akan tetapi sudah masuk kedalam wilayah peradilan umum begitu juga mengenai penyidiknya dimana untuk penyidik terhadap oknum anggota kepolisian yang melakukan tindak pidana yang bertindak sebagai penyidiknya adalah penyidik Propos atau Propam. Proses penegakan hukum bagi anggota Polri yang telah diperoleh bukti awal yang cukup sebagai pelaku tindak pidana, maka anggota Polisi itu, diserahkan kepada Ditreskrim, untuk disidik perkaranya, sesuai dengan ketentuan tahapan peradilan pidana sebagaimana diatur di dalam KUHAP, dan Undang Undang Nomor 35 Tahun 2009 tentang Narkotika. Dalam hal ini, Bid Propam bertugas memantau proses penanganan perkara dari anggota Polda bersangkutan sampai memiliki putusan pengadilan yang telah mempunyai kekuatan hukum tetap.

2. Penerapan sanksi terhadap anggota POLRI yang terbukti menggunakan narkotika Golongan I didasarkan pada putusan pengadilan yang telah mempunyai kekuatan hukum tetap, barulah pimpinan menjatuhkan sanksi pelanggaran Sidang Komisi 
Kode Etik. Berdasarkan Pasal 12 ayat (1) huruf a PP No. 1 Tahun 2003 tentang Pemberhentian Anggota Kepolisian Negara Republik Indonesia anggota POLRI tersebut terancam diberhentikan tidak hormat menurut pertimbangan pejabat yang berwenang tidak dapat dipertahankan untuk tetap berada dalam dinas Kepolisian Negara Republik Indonesia.

\section{F. Rekomendasi}

1. Seorang anggota POLRI hendaknya tetap menjaga dan memelihara komitmen kode etik terhadap profesinya sebagai sebagai pemelihara keamanan dan ketertiban masyarakat, penegak hukum serta pelindung, pengayom dan pelayan masyarakat, Institusinya yang menjadi wadah pengabdian yang patut dijunjung tinggi sebagai ikatan lahir batin dari semua insan Bhayangkara dan segala martabat dan kehormatannya, dan senantiasa bersikap netral, mandiri dan tidak terpengaruh oleh kepentingan politik, golongan dalam rangka menjaga tegaknya hukum Negara Kesatuan Republik Indonesia.

2. Peranan dan fungsi strategisnya peran Bidang Propam dalam menegakkan kehormatan dan kemuliaan martabat profesi kepolisian sebagai benteng penegakan hukum lebih ditingkatkan dan melakukan upaya-upaya penyedaran sistematik yang efektif dan efisien sehingga anggota POLRI menjadi personel-personel terbaik yang memiliki kompetensi teknis dan integritas moral yang tinggi.

\section{G.Daftar Pustaka}

Hari Sasangka, Narkotika dan Psikotropika Dalam Hukum Pidana,Mandar Maju, 2003, Bandung.

Soerjono Soekanto, Pengantar Penelitian hukum, UI PRESS, 1986, Jakarta,

Soerjono Soekanto dan Sri Mamuji, Penelitian Hukum Normatif "Suatu Tinjauan Singkat", PT Raja Grafindo Persada, Jakarta, 2004 